\title{
Theory at Odds with Best Practice: The Travails of Industrial Policy
}

\section{Irfan ul Haque}

\begin{abstract}
The problems that afflict Pakistan's manufacturing sector are widely known. It is also recognized that the current state of affairs must change, but there is little agreement as to what that might entail. The lack of consensus on required actions and policies can be traced back to the end of the era of rapid industrialization in the late 1960s and subsequent withering away of the "developmental state" as Pakistan could then be characterized. The industry's woes tend to be attributed to import substitution and high protection, with the policy implication that the country must further open up and liberalize. The paper questions this proposition and argues for a fresh approach to industrial policy, exploring what this might involve.
\end{abstract}

Keywords: Manufacturing, industrial policy, Pakistan.

\section{JEL classification: L52.}

\section{Introduction}

There is no other field of economics that generates more heat and controversy than industrial policy. The divergence of viewpoints on what is wrong with Pakistani industry and what ought to be done is evident among professional economists as well as policymaking circles. These differences have a long history and arise out of conflicting notions regarding industrial development and the role the government might play in promoting it. In an earlier paper, I have sought to show why industrial policy was required to promote international competitiveness and robust export growth in Pakistan (Haque, 2014). This paper takes the desirability and need for an articulated and coherent industrial policy as a premise, but goes forward in identifying the priority areas the country's policymakers should consider in designing one.

\footnotetext{
* The author is an unaffiliated researcher who has worked for the World Bank, South Centre, and UNCTAD. He wishes to thank Rashid Amjad, Shahid Amjad Chaudhry, Khalil Hamdani, and Akbar Noman for their perceptive and helpful comments on an earlier draft.
} 


\section{Origins of Pakistan's Manufacturing}

The rise of manufacturing is usually associated with domestic as well as international tensions. Domestically, new industry is perceived to upset the established rural-urban order, as the political balance shifts from the feudalists to the emerging class of industrialists. Internationally, existing producers react to the competition from new, emerging industrial centers with apprehension as specialization and trading patterns undergo profound changes. The emergence of new sources of manufactures is often taken as an outcome of unfair, even illegitimate, government practices involving commercial policy and currency manipulation.

Such tensions were evident in 19th century England when the new class of industrialists succeeded in having the ancient Corn Laws removed, thereby ending the protection that agriculture had hitherto enjoyed. Although less well known, the American Civil War too was in part a battle over differential government protection between the industrial North and the agricultural South (Chang, 2002). Economic rivalry among European countries over the capture of markets and access to sources of raw materials often led to war. Today's persisting tensions in the world economy are, at the bottom, a contest over control of resources and markets and disputes over whether governments are playing by the "rules."

Given this history, Pakistan's somewhat tortured struggle for industrial development is neither exceptional nor surprising. At the time of independence in 1947, the country's industry was rudimentary and mostly small-scale, while banking and insurance were largely in foreign hands. The initial motivation to industrialize arose out of a concern over the new nation's survival in the face of economically and militarily dominant India. Pakistan, by and large agricultural, produced jute in what was then East Pakistan and cotton in West Pakistan, while the factories processing these raw materials into manufactured products were mostly in India. Although self-sufficient in food, its agriculture too depended on rivers flowing out of the neighbor's territory. This dependency made Pakistan - certainly, in perception - fragile and vulnerable, and influenced the country's choices and actions with respect to industrial development.

Commercial relations between the neighbors received a serious blow when Pakistan, by design or out of perversity (as many then maintained), chose not to devalue the Pakistani rupee in 1949 along with 
the British pound and other Sterling Area currencies. India was particularly annoyed because it now faced higher prices for its raw materials from Pakistan, even as it benefited from improved competitiveness. For this, Pakistan was duly punished with the suspension of imports of raw jute and cotton. This added to the imperative that the country should industrialize, and investments in jute and cotton mills began.

In short, Pakistan's early industrialization was essentially reactive, not born out of a grand vision of turning the country into an industrial power, as was the case in India and many other developing and socialist countries at the time. Pakistan adopted five-year plans, but its approach to economic development remained more or less ad hoc, eclectic, nonideological, and nonstrategic, fashioning policies and approaches "on the fly," as it were. A concerted effort at industrialization was, however, made during the early years, as commercial policy was directed at promoting manufacturing and institutions were established specifically to help finance and develop industry.

\section{Pakistan's Industrialization and its Detractors}

The pace of industrialization in the first two decades of independence was impressive; new domestic industries rose and a class of Pakistani entrepreneurs emerged. Starting from a very small base, manufacturing value added grew rapidly, reaching 8 percent a year in the 1950 s and about 10 percent in the 1960s. The growth rate was highest during 1960-65, before falling sharply in the aftermath of the 1965 war with India (which included suspension of foreign aid) and mounting domestic unrest against the Ayub regime.

During the period of high growth, the government - as was common then - relied on high tariffs accompanied by direct controls over imports, prices, and investment to achieve its economic goals. However, the Ayub government also took steps to streamline and rationalize the policy regime with the specific aim of improving economic performance, especially in manufacturing. The import of raw materials was liberalized and exports were promoted through a variety of measures - notably, the Export Bonus Scheme - but also fiscal incentives, offering tax rebates, tax holidays, and accelerated depreciation allowances. The government also introduced export performance licensing and pay-as-you-earn schemes (Kemal, 2006). 
Pakistan's ability to achieve high economic growth came to be seen by the US and international financing agencies as a model that other developing countries could emulate. An official Korean delegation even visited the country in 1962 to learn from its development experience. Since those heady days, however, the pace of industrialization, and economic performance generally, has remained lackluster, leaving aside short-lived spurts in growth during the 1980s and 2000s.

Five decades ago, Pakistan's per capita income and other development indicators were roughly comparable with those of the East Asian economies. Today, it lags far behind on virtually all measures. Despite years of industrialization, manufacturing still accounts for less than 15 percent of GDP, compared to roughly 25 percent in Malaysia and Indonesia (Figure 1).

Figure 1: Manufacturing as a percentage of GDP, South Asia

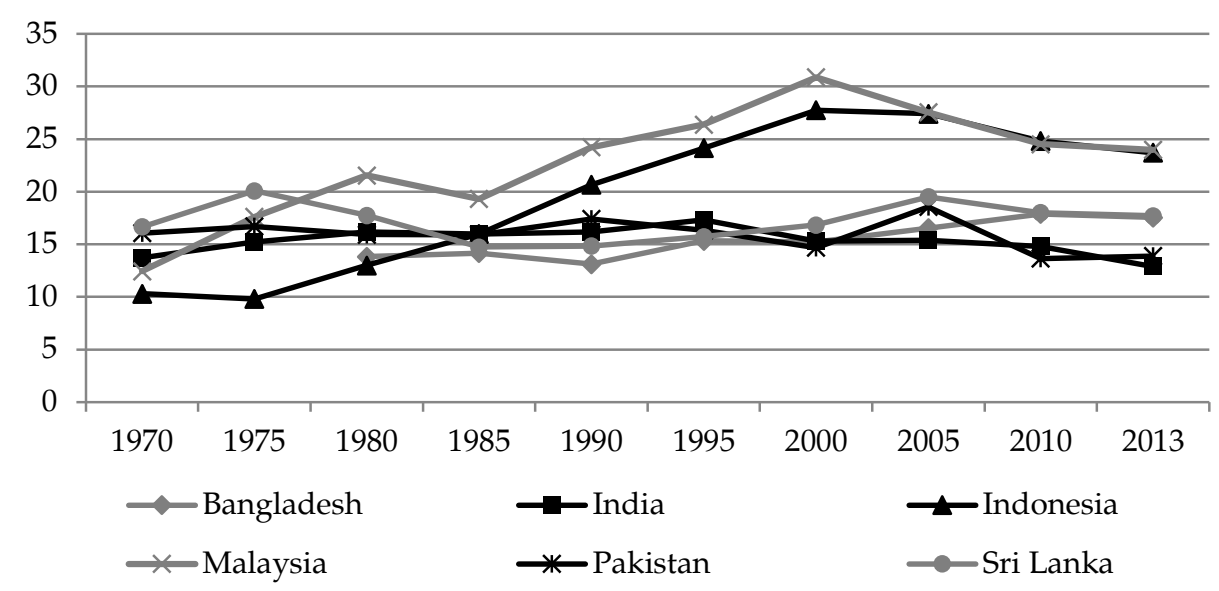

Source: World Development Indicators (http://data.worldbank.org/data-catalog/worlddevelopment-indicators).

However, in this respect, the other South Asian economies do not seem to have done much better. India's rapid economic growth over the last two decades was not driven by manufacturing; in fact, the share of manufacturing in GDP fell to 13 percent in 2013 - the lowest in the region. The current Modi government is sufficiently concerned about lagging manufacturing to have launched a "Make in India" campaign. Sri Lanka's manufacturing sector just about kept pace with economic growth, notwithstanding the peaks reached in the mid-1970s and again in 2005. Bangladesh is the only country where the share of manufacturing rose more or less steadily. 
Pakistan's general economic malaise is captured in poor manufacturing growth, low and lagging productivity, lack of competitiveness, little diversification in manufacturing or exports, and generally low-technology industry. Explaining what brought about this state of affairs is, however, complex and contentious. As in other countries and contexts, the experts' "default" position has been to blame high protection and import substitution industrialization for industry's failures. This has been critics' standard refrain for the past 50 years, not just with respect to Pakistan, but also for developing countries generally.

Industry had barely taken root in Pakistan when research studies (mostly by foreign scholars) brought out that its industry benefited from very high rates of "effective" protection and that domestic value added, when calculated in terms of "international" prices, was low or negative in key industries. In other words, the new industry in Pakistan was a waste of resources and the government's efforts at industrial promotion misguided. Prominent among these studies were Soligo and Stern (1965) and Lewis and Guisinger (1968), although subsequently Pakistani researchers too undertook similar exercises - notably, Kemal (1978) and Naqvi and Kemal (1983) - with broadly similar conclusions. A few Pakistani researchers challenged these findings and argued that the alleged inefficiencies of Pakistan's industry were much exaggerated (see, for example, Noman, 1991), but the dominant narrative remained untrammelled.

The preoccupation with protection and import substitution has not abated, and recent studies have continued to assert the harm this has done to the country (see, for example, Kemal, 2006; Hussain \& Ahmed, 2011; Pursell, Khan, \& Gulzar, 2011). The late Dr A. R. Kemal identified import substitution as the source of virtually all the ills plaguing Pakistan's industry. He observed (p. 50, 2006):

Low quality of products, lack of standardization, low value added products [are] sold without any brand names, lack of innovation, and low levels of productivity are the legacy of import substitution industrialization and indicate the need for major restructuring of the manufacturing sector [emphases added].

He further noted (p. 55):

While trade policy reforms in recent years have exposed domestic enterprises to international competition, these 
enterprises continue to suffer from the legacy of import substitution and have yet to reposition themselves to compete effectively in the global market [emphases added].

The policy conclusion of this diagnosis would appear to be: remove protection and liberalize foreign trade. The conviction that protection and import substitution are plainly bad for a country is widely shared, but remains questionable in terms of both theory and empirical evidence. The theory maintains that economic transformation, i.e., import substitution, occurs as countries attempt to catch up with the more advanced economies and build up their capital, technology, and skills.

This process inevitably entails mimicking advanced countries by replacing previously imported goods with domestic production. In other words, import substitution is bound up with industrialization and economic growth. Even within the narrow confines of the neoclassical model of international trade, accumulation of the relatively scarce factor leads to increased domestic production of the importables. Thus, import substitution is neither inherently inefficient nor inconsistent with theory.

Pakistan's industrialization was not overly dependent on import substitution. Kemal's own data (2006, table 3) show that the contribution of import substitution (however measured) to the overall growth of manufacturing was quite high in the early phase of industrialization, but became negligible or even negative after the late 1980s. This suggests that the "legacy of import substitution" - such as it was - dissipated over time. Pakistan's early industrial development was not too different from that of other developing countries in that it concentrated on setting up light consumer goods industry based on domestic raw materials as well as basic chemicals and building materials (fertilizer, cement, etc.). These product lines were promoted on the grounds that they either enhanced foreign exchange earnings through greater domestic value addition or saved foreign exchange by replacing imports.

That Pakistan's economy has been exceptionally protected or that high protection was the principal cause of industrial inefficiencies are also doubtful propositions. For one thing, measures of "effective" protection suffer from highly shaky foundations, given the serious snags in estimating reliable input-output ratios at a sufficiently disaggregated level, international prices, and appropriate exchange rates, which are required to 
measure effective protection rates. ${ }^{1}$ They are, at best, guesstimates, not to be trusted for diagnostics or as a policy guide. Thus, while the inefficiencies of Pakistan's industry are well known, it is less clear that protection was their main cause and its removal the key remedy.

Pakistan compares rather favorably with India when nontariff barriers are taken into account, and yet the latter's economic performance in recent years has been far superior to that of Pakistan (Pasha \& Imran, 2012). A recent World Bank (2013) report notes:

Although India has steadily opened up its economy, its tariffs continue to be high when compared with other countries, and its investment norms are still restrictive. This leads some to see India as a 'rapid globalizer' while others still see it as a 'highly protectionist' economy. [...] India however retains its right to protect when need arises. Agricultural tariffs average between 30-40 percent, antidumping measures have been liberally used to protect trade, and the country is among the few in the world that continue to ban foreign investment in retail trade. Although this policy has been somewhat relaxed recently, it remains considerably restrictive.

Statutory regulatory orders (SROs) have also been identified as arbitrary, opaque devices that undermine trade liberalization. However, while they may not be an efficient or objective means of helping individual industries or firms, there is not much evidence to suggest that they have been systematically protectionist. A recent study reports that, in some cases, SROs served to raise import tariffs, but these were mostly related to exempting producers from the payment of import duties (Pursell et al., 2011).

If openness is measured in terms of the trade/GDP ratio, Pakistan again appears to have been no more closed than some of its neighbors (Figure 2). Until the mid-1990s, Pakistan was significantly more open than China, India, or Bangladesh, though less so than Indonesia. The subsequent fall in this ratio was not due to increased protection - the country was engaged in trade liberalization at the time - but a result of the sharp fall in imports due to severe foreign exchange shortages and the

\footnotetext{
${ }^{1}$ Noman (1991) identifies other deficiencies in the measure of effective protection, notably, firms' tendency to underreport output and over-report inputs in order to lower reported profits and thereby reduce payment of excise and sales taxes.
} 
collapse of economic growth following the nuclear tests of 1998 and the suspension of foreign aid.

Figure 2: Trade as a percentage of GDP

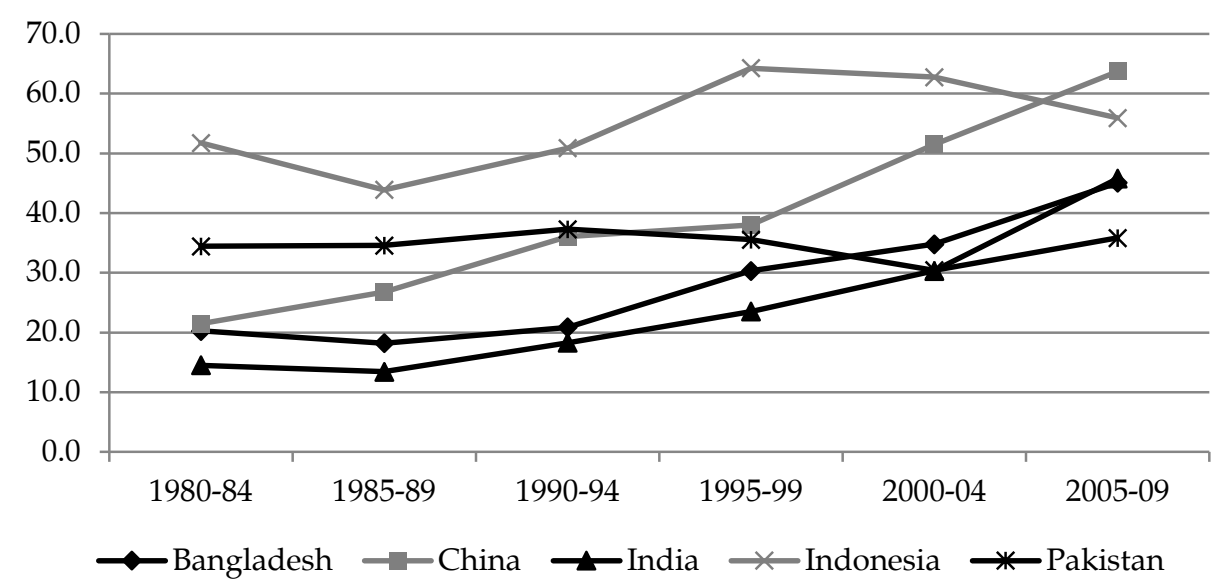

Source: World Development Indicators (http://data.worldbank.org/data-catalog/worlddevelopment-indicators).

All this is not meant to deny the benefits of openness, which include a country gaining access to products not produced domestically and to new technologies, while exposing its domestic firms to world competition. When protection is of autarkic proportions - as was the case in the Soviet Union or virtually so in India during 1950-80 - economic growth may be stifled and the economic cost of closure to trade can be exorbitant. Import liberalization in such situations is inevitably beneficial. Then, also, countries' trade regimes often suffer from inefficiencies: notably, redundant and overlapping import restrictions, and complicated rules and regulations governing foreign trade. Pursell et al. (2011) describe how such problems afflict Pakistan. Here, too, the rationalization of trade policy could be expected to yield quick and sizeable dividends.

What is being questioned here is the tendency to exaggerate the impact of trade policy on a country's manufacturing performance, something for which the proponents of both free trade and protection have shown a weakness. One group counts on trade liberalization to bring about efficiency and economic growth, while the other argues equally fervently that the nascent industry's survival depends on protection. The reality is that industrial performance depends on a range of factors that tend either to be overlooked or not given sufficient importance, as was the case in most policy reform programs undertaken 
with or without the support of the World Bank and other international development agencies.

Thus, there have been cases of industrialization failure under protectionist regimes as well as collapsing industries following import liberalization. Pakistan's experience is testimony to this: trade liberalization since the 1990s has done little to improve industrial efficiency or raise economic growth. Pakistan entered into a bilateral trade agreement with China in 2007 that greatly improved market access for Chinese exports, but did little to improve Pakistan's industrial competitiveness (Haque, 2009). Generally, there is little evidence that more open economies tend systematically to do better than less open ones, or that the latter start performing better post-trade liberalization. The important exception is when the opening up forms part of a broader program of industrial restructuring and policy reform, as was the case, for example, in China during the 1980s.

Given evolving trading patterns and the changing basis of specialization, import substitution cannot be dismissed simply because it violates a country's given "comparative advantage" (Haque, 2014). The process of trade liberalization and the rise of China and other low-cost producers in world trade have, today, reduced Pakistan to importing products it used to produce and even export. This happened because other countries started to produce more competitively products they had previously imported. There is no reason why, under proper conditions, Pakistan too cannot recapture its competitive edge and replace current imports with domestic production. A serious blunder on the part of Pakistani policymakers and private industry was their failure to heed the new trade winds: little was done to meet the challenges and take advantage of the opportunities they presented to the country.

\section{Travails of Industrial Policy}

In the first two decades following independence, but mainly under the Ayub regime, Pakistan could be said to approximate a "developmental state." The government's proactive role in promoting economic development was widely accepted and the economy's performance particularly in agriculture and industry - was held to be critical to its popularity, even legitimacy. However, in the late 1960s, even as the economy continued to grow, discontent increased with the rising income disparities between the country's two wings as well as across income classes. As the struggle for independence intensified in what was then East 
Pakistan, the country's leading economists, including one who could reasonably take credit for the successes of the Ayub regime, ${ }^{2}$ raised alarm at the increasing concentration of wealth among the so-called "22 families."

Naseemullah and Arnold (2015) maintain that Pakistan fulfilled the basic preconditions of a developmental state during the early decades. For one, as in the case of Korea and Taiwan, the compulsion to industrialize was driven by a sense of "systemic vulnerability" in the absence of adequate and dependable rentier income "that could both fund defense spending and buy off key constituencies" (p. 8). For another, the country had a bureaucracy that was able to co-opt the private sector into investing in Pakistan's future and hold it - albeit not systematically or consistently - accountable for its performance in exchange for special fiscal and commercial policy concessions. This was when the Pakistani civil service, with occasional support from the army, virtually ran the country and managed the economy while the country's politicians were entangled in fights over constitutional questions and interpersonal rivalries.

Rodrik (2004, p. 3) underscores the "need to embed private initiative in a framework of public action that encourages restructuring, diversification, and technological dynamism beyond what market forces on their own would generate." Pakistan more or less met this requirement. Naseemullah and Arnold (2015, p. 10) observe that, "autonomy and embeddedness were virtually guaranteed by the fact that bureaucracies [in Pakistan and Turkey] essentially created cohesive industrial bourgeoisies out of a disparate set of traders and merchants." But unlike Korea and Taiwan, the developmental state in Pakistan started to wither after the 1960s - a phenomenon the authors describe as being a failure of "the politics of developmental persistence" (p. 4). They go on to say: "The continuing consensus behind industrialization led Korea and Taiwan to maintain commitments to industrial investment and upgrade successfully, whereas fragmentation of support in Pakistan ... led to challenges to extant industry that prevented such upgrading" (p. 14).

\footnotetext{
2 The late Dr Mahbub ul Haq, who was chief economist at the Pakistan Planning Commission during the 1960s, proclaimed in a speech in 1968 that 22 industrial family groups had come to dominate the country's economic and financial life: they controlled about two thirds of industrial assets, 80 percent of banking, and 79 percent of insurance. However, a few years later, he offered a more nuanced assessment of the situation: "The slogan of 22 families ... has been rather overdone in Pakistan and taken too literally. At times, it has become a convenient camouflage for action against a few individual industrialists rather than reforming the economic as well as social and political institutions. This is sad because the 22 families are a symptom, not a cause. The basic problem is not the 22 families, individually or collectively, but the system that created them" (Haq, 1973).
} 
The fall of the Ayub regime and the abject end to the "Decade of Progress" dealt a serious blow to the developmental state in Pakistan. The final nail in the coffin was, ironically, the nationalization of industry and banking under the Bhutto government in the early 1970s. ${ }^{3}$ A step that might have been a pillar of an activist state ended up causing capital to take flight, and private capital has, to this day, not quite forgotten or forgiven that instance of government heavy-handedness.

The nationalization, which was a key part of the Pakistan People's Party's agenda and vision for the country, fell victim to political opportunism and personalized attacks on the industrialist class. Its scope was subsequently widened beyond what was originally envisaged with little regard for the longer-term consequences for industrial development. The other target of Bhutto's government was the civil service itself, which, over time, was also made to lose its aura and authority in running the country. At a time when a strong bureaucracy could have been useful to ensure the viability of the nationalized industries, government institutions in charge of economic policy were allowed to weaken. Thus, the Planning Commission and other government agencies witnessed an exodus of several key experts for greener pastures, notably the World Bank and IMF.

The tide of neoliberalism during the 1980s, which Pakistan embraced readily and uncritically, made the government's active promotion of industrialization something undesirable, though individual businesses continued to receive government largesse in one form or another. Over time, the state institutions supporting industrialization were made powerless or allowed to wind up. This happened when world trade in manufactures was undergoing a profound change, trading relations were being redefined, and new opportunities for specialization were opening up. New technologies and management practices as well as the rise of global value chains made labor intensity in manufacturing less and less significant as a basis of competitiveness or specialization. The outsourcing of manufacturing production and deindustrialization of the industrialized world was the flip side of these developments.

Under these conditions, the traditional notion of comparative advantage based on relative factor endowments - always questionable could provide little policy guidance. The countries that were able to take

3 The Green Revolution also helped strengthen the feudal elites - who had been upset at Ayub Khan's rather modest land reforms of the early 1960s - relative to the industrial class, which arguably made Bhutto's nationalization of industry politically easier. 
advantage of these developments - virtually all in East Asia - did so under state guidance and support, which was required for the purpose of coordinating investments, encouraging innovation, adopting new technology, promoting industrial upgrading, and generally helping domestic firms to remain competitive and become strategic links in the global value chains. With the government's effectively hands-off approach to industrialization, it is no wonder that Pakistan was more or less left out of the historic transformation of the world economy and, today, finds itself stuck in producing low-technology, low value-added, labor-intensive products.

In brief, Pakistan has much catching up to do, which would require a serious, concerted effort to revive manufacturing. Few countries, it seems, have done without industrial policy. Rodrik (2004) observes that, "industrial policies have run rampant during the last two decades" (p. 29). While this suggests that industrial policy is back in vogue following the cold winter of neoliberalism, there remain different notions as to what it means and involves.

Countries routinely use regulations, credit policy, fiscal incentives, or even protective tariffs to help or punish industries or firms, but these measures may not constitute a coherent program of industrial promotion and development. It was this that distinguished the East Asian economies and several others (including, to some extent, Pakistan) that adopted policies with the specific purpose of promoting rapid industrialization, before neoliberalism rendered such policies anathema. With this background, the paper concludes by exploring how Pakistan might change course and devise a spelled-out approach to promoting and reviving manufacturing.

\section{Pakistan's Policy Challenge}

Government policies need to be made within a framework or a program for industrial promotion, but this is possible only if there is a measure of agreement within the country on the government's role, the need for disciplining markets, and the direction industrialization should take. Major economic reforms are practically impossible when the government's role in designing regulatory rules, redistributing income, and mobilizing and directing investment for longer-term growth remains in doubt. Unfortunately, as in other domains of public policy, views in Pakistan are deeply divided, not just professional opinion, but also among government departments. In discussing the "disharmony and 
conflicting opinions of Pakistan's policymaking institutions," Hussain and Ahmed (2011) observe:

The imperative need for industrialization is the view of the ministry of industries and production (MOIP) in Pakistan as well as that of the new growth strategy initiated by the Planning Commission and the authors of this paper. However, the point of controversy is the way this may be achieved. The MOIP believes Pakistan's industries need to be protected for the same reason this paper advocates that a level playing field should be created; i.e. to develop a vibrant industry (p. 2).

Although inter-departmental differences are not unusual or necessarily damaging, Pakistan's current economic leadership is not strong enough or sufficiently clear about its priorities to resolve them. Virtually all examples of successful economic reforms and transformation come from countries that had strong leaders committed to improving economic performance: Park in South Korea, Mahathir in Malaysia, Suharto in Indonesia, Lee Kwan Yew in Singapore, Deng in China and, more controversially, Manmohan Singh in India. Ayub Khan, too, could have been counted among these leaders but for the fact that his legacy was too short-lived. Given the current leadership vacuum, it is difficult to be optimistic about Pakistan being able to devise and adopt a coherent and spelled-out program to promote manufacturing. Still, it is useful to explore what that might be.

A recent report by Sanchez-Triana et al. (2014) on revitalizing industrial growth in Pakistan identifies various steps that the country needs to take to improve its manufacturing performance. It recommends infrastructure development, adopting green technologies to cope with climate change, taking advantage of opportunities in rural-urban migration, undertaking trade policy reform and, not least, pursuing skills development. In answering the question, how this industrial growth might be stimulated, the report has this to say (p. xi):

Part of the answer lies in setting the right conditions for manufacturing to blossom and reach its full potential. This potential exists because of Pakistan's growing labor force and rising urbanization and connectivity. Yet, Pakistan's largely low-skilled labor force, poor commercial environment, lack of adequate infrastructure, and its 
failure to diversify production and climb up the technology ladder prevent this potential from becoming reality [emphases added].

These are incontrovertible observations, underscoring as they do Pakistan's key deficiencies, but the report's approach is essentially laissez-faire, i.e., create the right conditions and good things will follow. This is questionable. The report focuses primarily on the supply side provision of infrastructure, skilled labor, etc. - and hardly addresses demand-side problems. There is little assurance that simply alleviating supply-side constraints would on its own revitalize manufacturing activity. What is, for example, the likelihood that increased power supply would actually relieve the shortages in the manufacturing sector, instead of ending up feeding private consumption? Similarly, education and training obviously merit far greater attention and investment, but the effort would be effectively pointless if skilled labor were not to find employment and immigrate to foreign countries instead.

The recommendations that Sanchez-Triana et al. (2014) present, would, if carried out, help to strengthen the economy's underpinnings especially where problems are particularly acute - but they are unlikely per se to bring about a real turnaround in Pakistan's manufacturing sector. Something more, perhaps also different, is required in terms of government policies and actions aimed at inducing the private sector and markets to achieve better manufacturing performance.

In Pakistan's case, three domains of public policy appear to be foundational to bringing about the needed economic transformation and change in business behavior conducive to manufacturing growth and rising productive efficiency. Any program for manufacturing revival in Pakistan must aim to (i) reduce management failures, (ii) create and strengthen domestic firms' links with the global value chains and, not least, (iii) define and pursue Pakistan's strategic interests in regional trade.

There are often calls for a program of industrial restructuring in Pakistan. However, this paper argues that the poor performance of manufacturing is not due so much to industry-specific failures that could have been avoided had the country chosen different industries as to generic problems that cover virtually the entire spectrum of industry. Of these, management failure is probably the most pervasive and serious. At this juncture, the primary concern of policymakers and the private sector ought, therefore, to be to make existing industry more efficient rather 
than look for new high-growth industries. The latter is obviously important for the longer-term sustainability of economic growth and international competitiveness, but little will be gained if the new industry too is afflicted by inefficiency and low quality.

That Pakistani state enterprises are generally poorly run is well known. In terms of its economic salience and size of investment, Pakistan Steel Mills is, arguably, the most egregious case of mismanagement, corruption, and political interference. Steel mills with similar design and scope thrived in other developing countries (for example, India and Iran, not to mention Korea's success with Pohang Steel) and witnessed capacity expansion over time. Pakistan Steel Mills never came close to reaching its potential and remained veritably sick and loss-making. ${ }^{4}$ Although not in manufacturing, PIA and Pakistan Railways - fairly successful enterprises at one stage - have also seen their performance collapse and become a heavy burden on state finances. The reason is, again, gross mismanagement.

However, management failure is not confined only to state enterprises. It is also pervasive in the private sector, as is evident from the high variability in plant-level efficiency over time and across firms. Poorperforming private firms, which could be expected eventually to go out of business, nevertheless survive for reasons ranging from government largesse to some peculiar source that yields monopoly rents (government licensing, location, access to a scarce resource, etc.). Although the quality of management depends on a range of factors, it is particularly sensitive to the incentives available to managers. Pakistan could learn much from the East Asian experience in devising incentives and penalties based on a set of rigorous firm-level performance criteria. Even in the advanced economies, the issue of rewards and managerial performance has gained prominence thanks to large-scale financial malfeasance and ill-considered short-term financial adventures by bankers and hedge fund managers.

Forging integral links with global value chains is also a management issue - ensuring quality, reliability, competitive costs and, not least, salesmanship - but it is also dependent on the firm's exposure to the global market, ability to meet international quality standards, and access to finance, where the government's role is often critical. As noted

\footnotetext{
${ }^{4}$ It is remarkable that, for a project the size of Pakistan Steel Mills and the fact that it has been a serious drain on public resources and had to be put up for sale to the private sector, there has been little serious research on why this venture failed to deliver on its promises. What are available are basically anecdotal and sensational newspaper accounts.
} 
earlier, Pakistan today faces competition mainly from other low-wage countries where firms, desperate to gain a slot in the value chain, look for ways to push wages down and allow labor and environmental standards to decline, often with open or tacit government connivance. This phenomenon - known as the "race to the bottom" - is ultimately selfdefeating and leads to much misery and hardship for the working poor, as became evident, for example, in Bangladesh not too long ago.

Such behavior can be avoided only if the countries concerned cooperate in disavowing such practices. Beyond that, domestic measures are needed to make firms compete on the basis of productivity and quality through sustained, continuous efforts at building skills and enforcing quality standards. In a rapidly changing global environment, "best practice" is not a fixed point but rather something that firms strive and compete to realize through incremental and sustained improvements in products and processes (Haque, 2014).

The third domain of public policy is taking advantage of regional trade, which gained in salience as developing countries became major players in the world market and the long-established North-South trade links weakened. It is now commonplace to claim Pakistan's geostrategic importance, but how this might redound to a national advantage is less clear and certain. As noted earlier, Pakistan has so far failed to take full advantage of its bilateral trade agreement with China.

In recent years, a vocal segment of the Pakistani business and professional community has pressed for closer commercial ties with India. However, given the experience with opening up to China, it is foolhardy to pin hopes on trade with India turning Pakistan into a manufacturing hub. Imports of manufactures from China and India have risen rapidly over the past decade, but that has done little to raise Pakistan's industrial prowess. If anything, a number of industries that erstwhile managed to thrive have now simply disappeared, thanks mainly to the flood of Chinese and Indian imports. Given this state of affairs, further opening up the economy to regional suppliers is likely only to make the survival of domestic industry even more difficult.

Commercial relations with India, as indeed with other regional economies, should grow and become stronger over time, but that can work to Pakistan's advantage only if a concerted effort is made at the level of the government and private sector to make domestic industry internationally competitive. Experience has shown that the realization of gains from 
international trade cannot be left entirely to the market, certainly not when an economy with relatively small firms must compete with foreign industrial giants, often backed actively by their governments.

How firms compete with each other is an important determinant of productive efficiency, the key to their viability in the world market. The choice is not between the market and government direction and planning, or between competition and monopoly, but rather one of fashioning markets that induce firms to compete in terms of improved productive efficiency. This is truly a big challenge for the country and its policymakers.

The market is normally expected to make firms compete on the basis of costs and quality, but competition often becomes dysfunctional when firms seek ways to hurt their competitors in order to get ahead and dominate the market. In unregulated markets - as during the early era of industrialization in the US and other Western economies and in many developing countries today - firms are inclined to eliminate competition and consolidate monopoly power. In this state of affairs, the victorious firms are seldom the more efficient, but rather those with deeper pockets (Haque, 2007). Anti-competitive practices persist even where countries have instituted rules and regulations against unfair trading practices and the rise of monopolies through mergers and acquisitions.

The Competition Commission of Pakistan has the mandate to prevent anti-competitive behavior and deter firms from exploiting their dominant position or adopting "deceptive marketing practices," though it has so far been concerned mostly with mergers and acquisition. However, if the goal is to create markets that are conducive to the rise of robust, internationally competitive firms, the Commission's mandate and regulatory authority will need to be broadened in three respects. ${ }^{5}$

The first concerns the institutional basis of the market. Free enterprise and competitive markets today have universal appeal, but there remain significant differences across countries as to what drives the market. There is a distinction between the economies that followed the so-called Anglo-Saxon model and those that followed the Continental/East Asian model, principally on grounds that, in one model, the stock market was the dominant source of financing investment, while in the other it was the banking system.

\footnotetext{
${ }^{5}$ If that is deemed impractical, some other agency will need to carry out the task.
} 
Although the distinction has now become quite blurred, ${ }^{6}$ it is a fact that, where share valuation and performance are dominant considerations, investments are motivated by shorter-term considerations. Rapid economic growth requires high rates of investment with longer-term objectives rather than speculative, get-rich-quick activities. Pakistan's economic growth has faltered because of its abysmally low investment rate and financial markets that encourage investors toward short-sighted ventures, such as real estate and speculation in the domestic stock exchanges.

Second, from the viewpoint of helping new firms to survive and grow, there is often a need to regulate competition so that firms innovate and develop new products and markets. Competitive pressure is useful to induce firms to invest in productivity and quality improvements, but it may need to be restricted, at least for a while, so that domestic firms become more established and stronger over time. This is not quite the traditional and notorious "infant industry argument" for restricting competition. Rodrik (2004) has called this the "discovery process," that is, "one where firms and government learn about underlying costs and opportunities and engage in strategic coordination" (p. 3).

Finally, there is a case for regulating competition where small domestic firms are threatened by larger foreign firms that have a competitive advantage simply because of their size, as they have easier access to finance and enjoy scale economies relating to R\&D, advertising and other sales costs, not to mention greater political influence (Haque, 2007). This requires carefully examining the causes of higher production costs and inefficiencies of domestic firms, and establishing whether increased competition would actually lead to improvements or just force firms out of business, as happened over the last decade.

It bears repeating that Pakistan's trade liberalization failed to yield productivity gains mainly because little attention was given to addressing the peculiar difficulties domestic firms face, in the belief that increased competition was all that was needed. All those who believe in liberalizing trade and freeing markets in Pakistan are urged to reflect on how markets and the free enterprise system work in practice.

\footnotetext{
${ }^{6}$ This has happened mainly because of the globalization of international finance and the consequent troubles confronting financial institutions.
} 


\section{References}

Chang, H.-J. (2002). Kicking away the ladder: Development strategy in historical perspective. London: Anthem Press.

Haq, M. (1973, March 22). System is to blame for the 22 wealthy families. The Times. Retrieved from http://mhhdc.org/ $\mathrm{p}=76$.

Haque, I. (2007). Rethinking industrial policy (Discussion Paper No. 183). Geneva: UNCTAD.

Haque, I. (2009). The rise of bilateralism in trade and its implications for Pakistan [Special edition]. Lahore Journal of Economics, 14, 111-133.

Haque, I. (2014). Toward a competitive Pakistan: The role of industrial policy [Special edition]. Lahore Journal of Economics, 19, 61-90.

Hussain, S. S., \& Ahmed, V. (2011). Experiments with industrial policy: The case of Pakistan (Working Paper No. 124). Islamabad: Sustainable Development Policy Institute.

Kemal, A. R. (1978). An analysis of industrial efficiency in Pakistan: 1959-60 to 1969-70. Unpublished PhD thesis, University of Manchester, UK.

Kemal, A. R. (2006). Key issues in industrial growth in Pakistan [Special edition]. Lahore Journal of Economics, 11, 49-74.

Lewis, S. R., \& Guisinger, S. E. (1968). Measuring protection in a developing country: The case of Pakistan. Journal of Political Economy, 76(6), 1170-1198.

Naqvi, S. N. H., \& Kemal, A. R. (1983). The structure of protection in Pakistan: 1980-81 (2 vols.). Islamabad: Pakistan Institute of Development Economics.

Naseemullah, A., \& Arnold, C. E. (2015). The politics of developmental state persistence: Institutional origins, industrialization, and provincial challenge. Studies in Comparative International Development, 50(1), 121-142.

Noman, A. (1991). Industrial development and efficiency in Pakistan: A revisionist overview. Pakistan Development Review, 30(4), 849-861. 
Pasha, H. A., \& Imran, M. (2012). The prospects for Indo-Pakistan trade [Special edition]. Lahore Journal of Economics, 17, 293-313.

Pursell, G., Khan, A., \& Gulzar, S. (2011). Pakistan's trade policies: Future directions (Working Paper No. 11/0361). London: International Growth Centre.

Rodrik, D. (2004). Industrial policy for the twenty-first century. Unpublished manuscript prepared for UNIDO. Retrieved from https://www.sss.ias.edu/files/pdfs/Rodrik/Research/industrial -policy-twenty-first-century.pdf

Sanchez-Triana, E., Biller, D., Nabi, I., Ortolano, L., ... Enriquez, S. (2014). Revitalizing industrial growth in Pakistan: Trade, infrastructure, and environmental performance. Washington, DC: World Bank.

Soligo, R., \& Stern, J. J. (1965). Tariff protection, import substitution, and investment efficiency. Pakistan Development Review, 5(2), 249-270.

World Bank. (2013). India: Foreign trade policy [Webpage]. Retrieved from http://web.worldbank.org/WBSITE/EXTERNAL/COUNTRIES/ SOUTHASIAEX

...:579454 pagePK:34004173 piPK:34003707 theSitePK:579448,00. html 